\title{
Modelling of the distribution of Biomphalaria glabrata and Biomphalaria straminea in the metropolitan region of Recife, Pernambuco, Brazil
}

\author{
Verônica Santos Barbosa, ${ }^{1}$ Ricardo José de Paula Souza e Guimarães, ${ }^{2}$ \\ Rodrigo Moraes Loyo, ${ }^{1}$ Constança Simões Barbosa ${ }^{1}$ \\ ${ }^{1}$ Centro de Pesquisas Aggeu Magalhães, Fundação Oswaldo Cruz, Recife; \\ ${ }^{2}$ Instituto Evandro Chagas, Ananindeua, Brazil
}

\begin{abstract}
The occurrence of schistosomiasis is directly linked to the presence of its snail intermediate host Biomphalaria spp. Knowledge of geographical distribution, habitats and behaviour of these snails in relation to the climate is essential for guiding measures for disease prevention and control. This study aims to model the distribution of $B$. glabrata and $B$. straminea in schistosomiasis non-endemic areas of the metropolitan region of Recife (MRR) based on environmental data and estimates of snail distributions in endemic and neighbouring areas. We applied Kriging with the aim of determining the spatial distribution of these two snail species and MaxEnt for modelling their ecological behaviour. Kriging showed that the North and the Centre of the MRR were generally either snail-free or contained only $B$. straminea, while both snail species could be found in the South. MaxEnt supported our observation that the northern and southern coastal regions were favoured by B. glabrata and diurnal mean temperature variation; July rainfall and November rainfall were the three variables favouring Biomphalaria breeding sites that contributed the most in the predictive model we developed. The study showed the location of areas suitable to Biomphalaria spp. and therefore
\end{abstract}

Correspondence: Verônica Santos Barbosa, Centro de Pesquisas Aggeu Magalhães-CPqAM/Fiocruz-PE, avenida Professor Moraes Rego, s/n - 50, 740465 Recife/PE, Brazil.

Tel: +55.081.21012661/081.996710499 - Fax: +55.081.4531911.

E-mail: sbveronica85@hotmail.com

Key words: Schistosomiasis; Biomphalaria; Geospatial techniques; Brazil.

Acknowledgments: to the staff of Schistosomiasis Laboratory of the Research Center Aggeu Magalhães-Fundação Oswaldo Cruz, FACEPE (Amparo Foundation Science and Technology of Pernambuco) and CAPES Brazil Program Without Misery.

Received for publication: 2 June 2016.

Revision received: 12 September 2016

Accepted for publication: 18 October 2016.

(C) Copyright V. Santos Barbosa et al., 2016

Licensee PAGEPress, Italy

Geospatial Health 2016; 11:490

doi:10.4081/gh.2016.490

This article is distributed under the terms of the Creative Commons Attribution Noncommercial License (CC BY-NC 4.0) which permits any noncommercial use, distribution, and reproduction in any medium, provided the original author(s) and source are credited. at potential risk, first for invasion of these snails and later for the development of new schistosomiasis-endemic areas. This information should be useful, not only to estimate expansion possibilities of this disease in the MRR, but also to point out the climatic variables that would contribute to this expansion, thereby allowing timely application of prevention and control measures.

\section{Introduction}

The snails that host schistosomiasis belong to class Gastropoda, family Planorbidae, genus Biomphalaria. In Brazil, eleven species and one subspecies of Biomphalaria (Preston, 1910) have been described: B. glabrata, B. straminea, B. tenagophila, B. peregrina, B. schrammi, $B$. kuhniana, $B$. intermediai, $B$. amazonica, $B$. oligoza, $B$. occidentalis, $B$. cousini and $B$. tenagophila guaibensis but only the first three of these are found to be naturally infected with Schistosoma mansoni (Brazilian Ministry of Health, 2009, 2014). B. glabrata is the main intermediate host given its wide geographical distribution and the fact that it presents high levels of infection, while $B$. straminea is the most successful species given its capacity to adapt to climatic variations. $B$. tenagophila has epidemiological importance for transmission of $S$. mansoni in the states of the southern and south-eastern Brazil (Brazilian Ministry of Health, 2014). The genus Biomphalaria has existed since the Jurassic period (approximately 140 million years ago). It is directly influenced by the environment in which it lives and has developed a variety of survival strategies (Brazilian Ministry of Health, 2014). These snails' habitats consist exclusively of freshwater bodies with little water velocity (less than $30 \mathrm{~cm} / \mathrm{sec}$ ), such as rivers, streams, channels and flooded areas, preferably with little depth (Barbosa and Barbosa, 1994; Pieri and Favre, 2008). There are even reports of the existence of these snails in puddles, drains and flooded, vacant land (Barbosa et al., 2001, 2004; Silva et al., 2006; Souza et al., 2008). The presence of vertical or floating vegetation contributes food and shelter and provides support for spawning, which is always done on when the snails are submerged (Brazilian Ministry of Health, 2014). Presence of schistosomiasis has been described in 18 of the states of Brazil, including the Federal District, and its occurrence is directly linked to the presence of Biomphalaria (Brazilian Ministry of Health, 2009). In the state of Pernambuco, B. straminea is endemic in the Zona da Mata region, with some records also on the coast of this state, while B. glabrata occurs in the coastal region (Barbosa et al., 2010, 2014). Knowledge of these snails' habitats, behaviour in relation to climate change and geographical distribution is essential for guiding measures for prevention and control of schistosomiasis.

Geospatial techniques were first applied to studies on schistosomiasis in the Philippines and in the Caribbean (Cross and Bailey, 1984). 
In Brazil, use of geographical information systems (GIS) in relation to schistosomiasis occurred initially in Bahia (Bavia et al., 1999). They constructed maps showing environmental characteristics, prevalence of $S$. mansoni and its snail host in order to study the spatial and temporal dynamics of the infection thereby providing an indication of the environmental factors that influence the distribution of schistosomiasis Geostatistical techniques such as Kriging (Isaaks and Srivastava, 1989) and MaxEnt (Elith et al., 2011) were initially applied in the field of mining and assessment of mineral resources, and later for studies of plant and animal ecology.

Kriging is a spatial estimation technique that can be used to build probabilistic models for values not sampled, allowing inferences from observed values (Felgueiras, 1999; Shad et al., 2009). Indicator Kriging for categorical data takes into consideration the uncertainties associated with the data and methods involved in modelling, thus enabling creation of maps of snails spatial distributions along with the corresponding uncertainties (Felgueiras, 1999). MaxEnt is a maximum entropy approach to species distribution that allows estimation and modelling of species distribution based on environmental characteristics (Phillips et al., 2004). This means that places with similar climatic and other environmental characteristics are likely to present biomes suitable to the same plants and animals (in this case snails). Biomes are distinct from habitats because any biome can comprise a variety of habitats.

Since the beginning of this century, several authors have started to use these techniques also towards advancing human health (Campos et al., 2002; Fortes et al., 2004; Lourenço and Landim, 2005; Castro and Singer, 2007; Cardim et al., 2013; Samy et al., 2014). In particular, these techniques have been used to model diseases such as schistosomiasis in studies developed by Guimarães et al. $(2009,2010,2012)$ to estimate the spatial distribution of Biomphalaria snails in the state of Minas Gerais. Furthermore, Scholte et al. (2012) used modelling based on environmental characteristics with this aim in the whole country. These studies are based on data from the literature and the authors point out that there is a need for new studies using primary, georeferenced data derived from malacological surveys.

The present study had the aim of modelling the distribution of $B$. glabrata and B. straminea in non endemic areas of the metropolitan region of Recife (MRR), Pernambuco based on estimates of the distribution of the species in neighbouring areas and environmental data.

\section{Materials and Methods}

\section{Study area}

The study was carried out in MRR that is characterized by a tropical humid climate or pseudo-tropical climate according to the Koppen classification (Alvares et al., 2013), with rain well distributed throughout the year but with the months May to July the wettest and October to December the driest. The average annual temperature of the area is $24^{\circ} \mathrm{C}$, ranging from 18 to $32^{\circ} \mathrm{C}(\mathrm{CPRH}, 2003 \mathrm{a})$.

The hydrography of the area is made up of coastal and transcoastal rivers. The costal river begins and flow into the coastal zone is in general perennial, although small in size, play an important role in maintaining ecosystems and communities. The transcoastal begins in the region Agreste of Pernambucano, where they present a temporary basis, becoming perennial to penetrate the Forest Zone, have wide scope and large number of tributaries and flow into the coastal zone (CPRH, 2003b).
The geological structure of the MRR consists of tertiary, quaternary and recent deposits (marine terraces and mangrove deposits). In the East, the coastal plain forms a geological relief of sedimentary origin with variable width and an altitude from 0 to $10 \mathrm{~m}$. This includes features, such as beaches, salt marshes (marine terraces), mangroves (marsh or muddy formations), temporarily and permanently flooded river floodplains and terraces bordering the terminal course of rivers. In the West, the coastal plain ends with hills and mountains that rise up to $400 \mathrm{~m}$ (CPRH, 2003a, 2003b).

The vegetation consists of remnants of the Atlantic Forest that covered the area up to the colonial times, but which has now been replaced by agriculture with sugarcane and coconut as the main produce. Implementation of allotments and logging for firewood added to the destruction of the forests. The land along the coastal strip is subject to constant tidal forces of the sea, which favours mangrove vegetation, which remains relatively conserved (CPRH, 2003a, 2003b).

\section{Spatial analysis}

To model the spatial distribution of the intermediate snail host of schistosomiasis, the following two geospatial techniques were applied: Kriging, with the aim of estimate what species of Biomphalaria (with focus on quantity and proximity) would be most likely based on information from neighbouring areas; and MaxEnt for estimate and modelling of the distribution of the species of snails based on ecological behaviour.

\section{Kriging}

To estimate the distribution of Biomphalaria, geolocation data for the localities distributed across the 14 municipalities of the MRR were used. We used categorical Kriging to take into account uncertainties associated with the data and methods involved in the models, thus enabling creation of random fields equiprobable. The conditions for the positive localities were that $B$. glabrata only, $B$. straminea only or $B$. glabrata $+B$. straminea were present, while areas where there were no snails were considered negative. For the municipalities for which there was no information regarding the geolocation of Biomphalaria, the attributes (presence or absence of snails) were distributed across the six hydrographic basins of Pernambuco that were present within the study area, in accordance with the methodology suggested by Guimarães et al. (2009). This methodology consists of distribute a point sequence along the drainage network when there isn't a geolocation of breeding places.

A total of 290 points were used in the categorical Kriging according to indication. Variogram models that are used to characterization of spatial correlation through creation of experimental semivariograms were fitted for each class of Biomphalaria, through exploratory analysis, using the geostatistical procedures of SPRING software (Câmara et $a l .$, 1996). These procedures involve the creation of user-interactive semivariograms, which were adjusted using theoretical mathematical models (spherical, exponential, Gaussian or potency models). After fitting the models, their appropriateness in relation to the theoretical models was verified according to Camargo (1997). Following this, categorical Kriging procedures were applied as indicated. The snail spatial distribution maps, with a spatial resolution of $100 \mathrm{~m}$, along with their corresponding uncertainties, which can vary from 0 to 1 , were constructed using ArcGis 10 (http://www.esri.com/software/arcgis/), based on estimated functions.

\section{MaxEnt}

We used MaxEnt (https://www.cs.princeton.edu/ schapire/maxent) 
to estimate and model the distribution of Biomphalaria spp. snails based on environmental variables; 67 climate data were used. The 19 monthly, bioclimatic variables (http://www.worldclim.org /bioclim) were obtained from Worldclim Global Climate (http://www.worldclim.org/), which provides monthly climatic information interpolated from meteorological stations over a 50 -year period (1950-2000) with 1-km spatial resolution (Table 1). We applied MaxEnt with 441 georeferenced points to estimate the occurrence of species of the schistosomiasis intermediate host snails $B$. glabrata and $B$. straminea. The models produced were implemented through the MaxEnt software, the configurations used were: random teste percentage of $30 \%$ and 10 replications to enable a better data representation. The other resources were selected automatically. The performance of the model was ascertained using the area under the curve (AUC) of the receiver operating characteristic (ROC) curve, which measures the exactness of the predictive distribution models. The final models were plotted at a spatial resolution of $1 \mathrm{~km}$ using the ArcGis software.

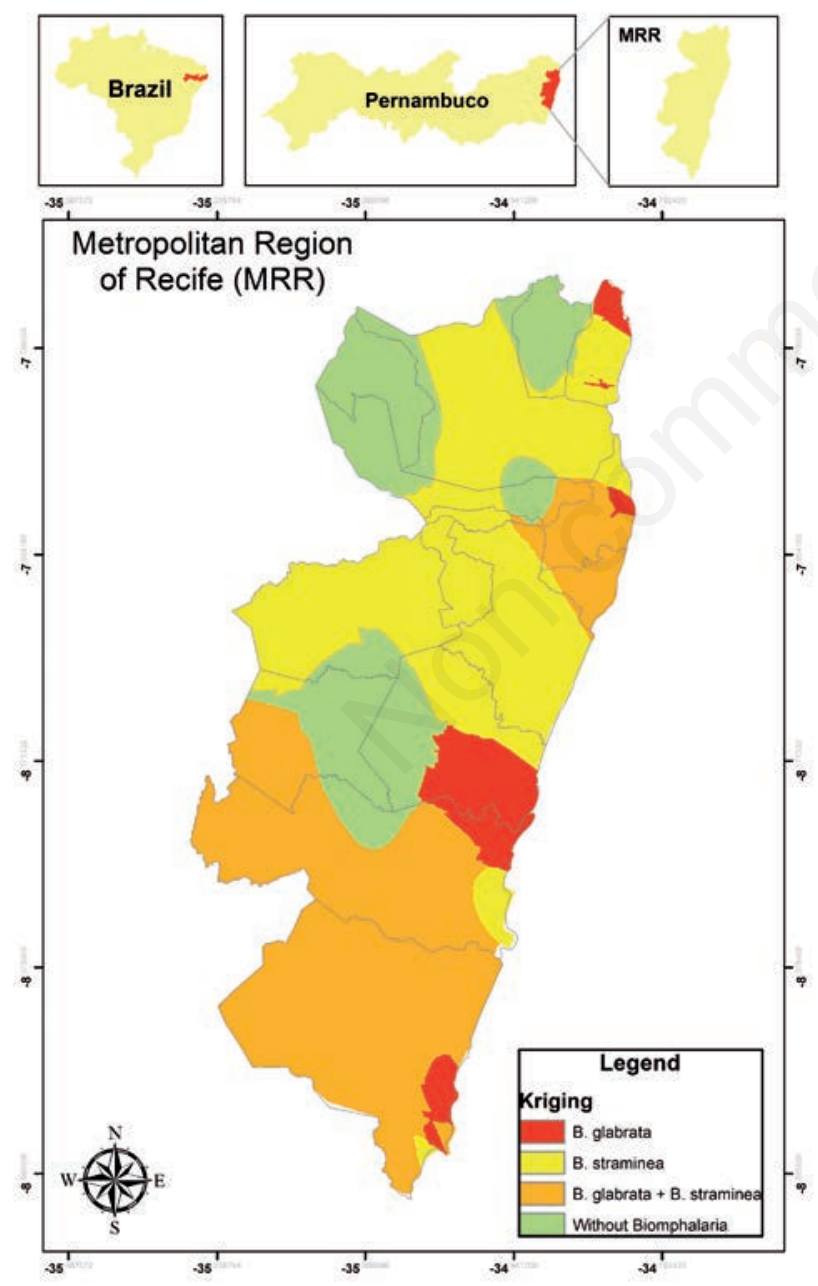

Figure 1. Spatial distribution of Biomphalaria in the metropolitan region of Recife obtained by Kriging.
Table 1. Worldclim global climate variables.

\begin{tabular}{ll}
\hline Variable & Code \\
Annual mean temperature & Bio 01 \\
Mean diurnal range & Bio 02 \\
\hline Isothermality & Bio 03 \\
Temperature seasonality & Bio 04 \\
\hline Maximum temperature of the warmest month & Bio 05 \\
Minimum temperature of the coldest month & Bio 06 \\
\hline Annual temperature range & Bio 07 \\
Mean temperature of the wettest quarter & Bio 08 \\
\hline Mean temperature of the driest quarter & Bio 09 \\
Mean temperature of the warmest quarter & Bio 10 \\
\hline Mean temperature of the coldest quarter & Bio 11 \\
Annual precipitation & Bio 12 \\
\hline Precipitation of the wettest month & Bio 13 \\
Precipitation of the driest month & Bio 14 \\
\hline Precipitation seasonality & Bio 15 \\
Precipitation of the wettest quarter & Bio 16 \\
\hline Precipitation of the driest quarter & Bio 17 \\
Precipitation of the warmest quarter & Bio 18 \\
\hline Precipitation of the coldest quarter & Bio 19 \\
\hline
\end{tabular}
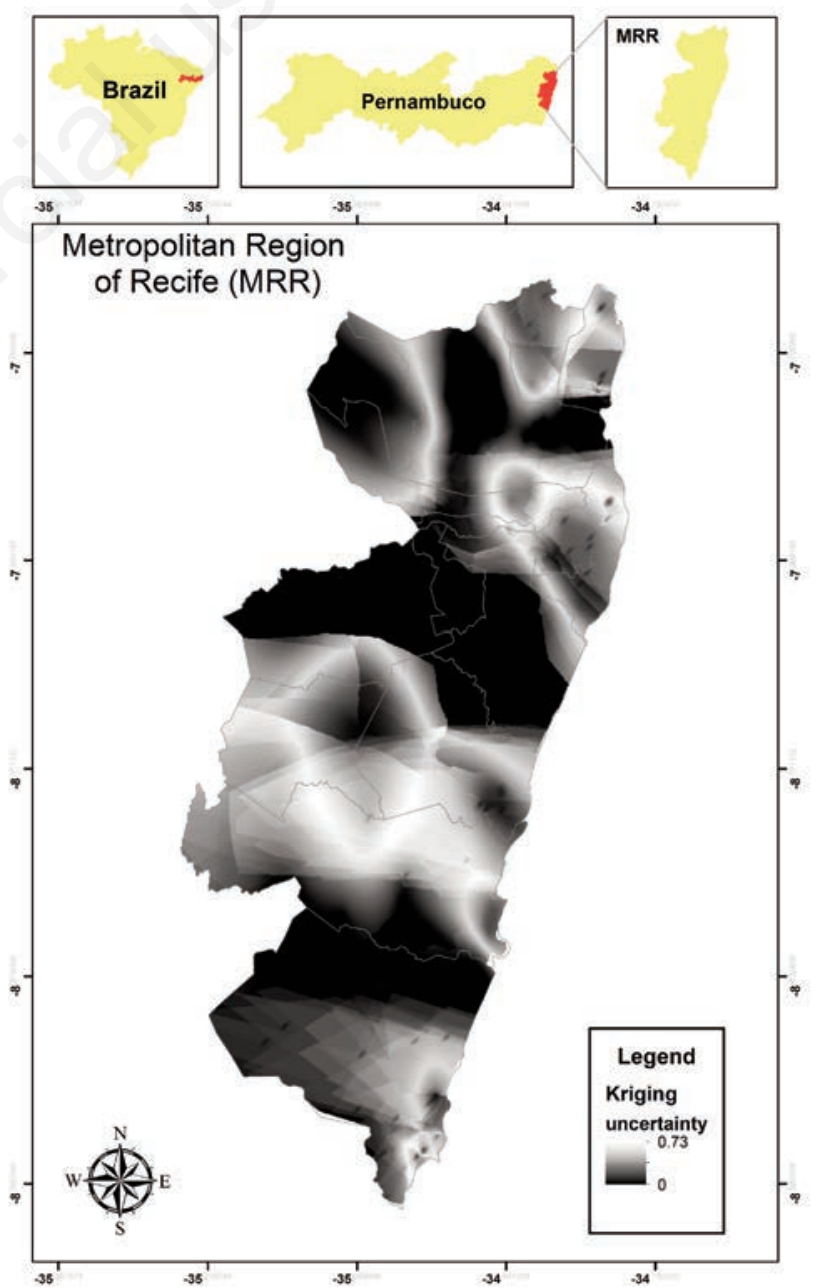

Figure 2. Demonstration of the area of uncertainty regarding the spatial distribution of Biomphalaria in the metropolitan region of Recife obtained by Kriging. 


\section{Results}

Figure 1 shows the result of applying categorical Kriging in MRR. It demonstrates that either $B$. straminea alone or complete absence of snails predominate in the North and Centre of the MRR, both B. glabra$t a$ and $B$. stramine $a$ coexist in the South. Figure 2 shows the 0.73 uncertainty map of the modelling. The uncertainties were higher in the transition areas between the two species.

Figures 3 and 4 show the MaxEnt results regarding the most likely areas for occurrences of $B$. glabrata and B. straminea in the MRR. The northern and southern coastal regions showed the greatest receptiveness for the former snail species, while the central area was favoured by the latter. The diurnal mean temperature suited both snail species equally well, while the variables particularly favourable for $B$. glabrata and which contributed most to the predictive model were the diurnal mean temperature, July rainfall and November rainfall, while in the case of $B$. straminea it was November rainfall. With an AUC of 0.999 , the predictive capacity of the models was high.

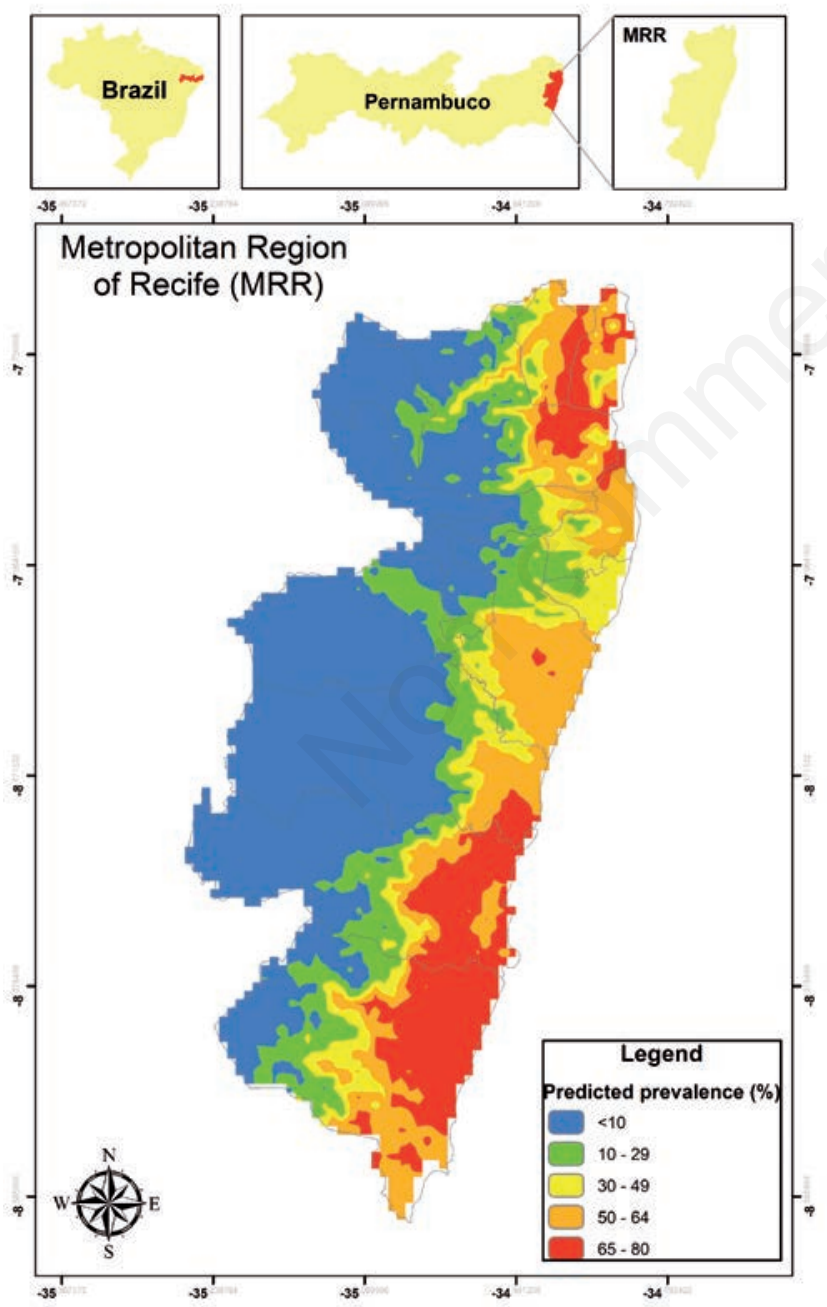

Figure 3. Spatial distribution of Biomphalaria glabrata in the metropolitan region of Recife obtained by MaxEnt.

\section{Discussion}

Knowledge of the density, dynamic population and distribution of Biomphalaria snails is an important tool for planning schistosomiasis control programs in the areas where these snails occur. In the present study, the use of categorical Kriging according to indication made it possible to ascertain the spatial distribution of Biomphalaria in the MRR based on the distribution of the two different species. One type of neighbourhood was clearly favoured by both species, while $B$. straminea was found alone in another. It has been pointed out that competitive exclusion influences the distribution of the species since the 1970 s, i.e. B. straminea showing dominance due to the biological characteristics of this species, such as high reproductive rate, invasiveness and relatively ease in adaptation to new environments (Barbosa et al., 2014). This has allowed its establishment in new locations, bringing with it the possible endemicity of schistosomiasis, e.g. in the forest zone of Pernambuco where this species is now common (Barbosa et al., 2006). The replacement process of $B$. glabrata by $B$.

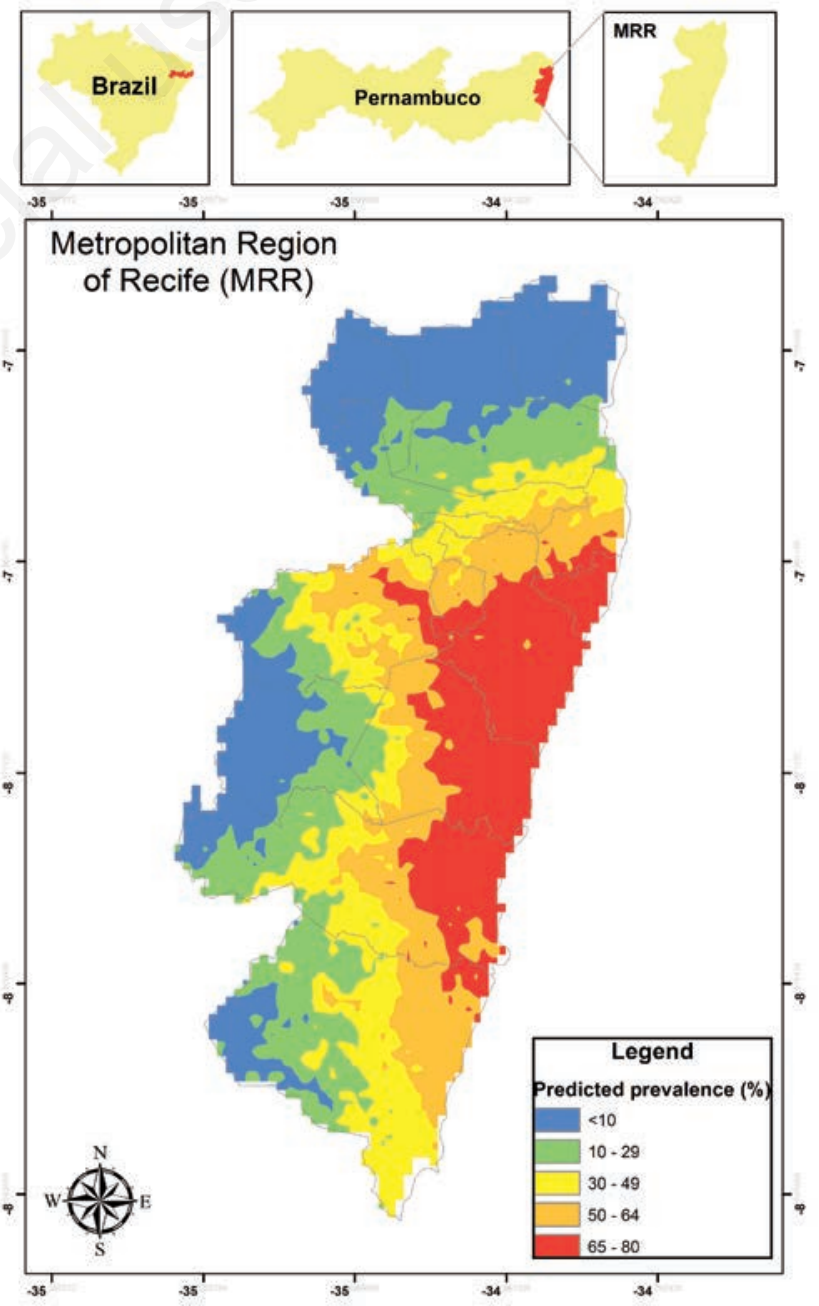

Figure 4. Spatial distribution of Biomphalaria straminea in the metropolitan region of Recife obtained by MaxEnt. 
straminea in the MRR was reported by Barbosa et al. in 2014. The uncertainty found in this study was very similar to that seen by Guimarães et al. in 2012. These authors reported a mean of 0.23 in estimates with greater certainty (100\% in the São Francisco River Basin) and 0.33 in estimates with lower certainty (67\% in the Paraíba do Sul River Basin), which supports the view that transitions and uncertainties will be greater in areas in which several species occur simultaneously. When modelling the distribution of Biomphalaria based on environmental characteristics, temperature and rainfall were the characteristics that contributed the most, which was also observed by Scholte $e t$ $a l$. (2012). Fluctuation of environmental temperatures and precipitation has a direct effect on the density of the snail populations studied. The hot season is most favourable for snail reproduction as it increases the microflora, which serves as an important nutritional source, while aquatic plants provide adequate dissolved oxygen and surface where the snails can crawl and deposit their egg masses (Malek, 1958). Increase in temperature also stimulates the release of cercariae (Lutz, 1919; Rey, 2008) with the optimum temperature for snail development is between 20 and $26^{\circ} \mathrm{C}$ (Barbosa and Barbosa, 1994), but temperatures from 18 to $41^{\circ} \mathrm{C}$ can be tolerated (Brazil, 2008). Rainfall influences the formation and expansion of snail breeding sites/foci (Barbosa and Barbosa, 1994). In the rainy season (May to August), Biomphalaria spp. populations decrease due to flooding, but there is accelerated snail growth and production of new individuals leading to repopulation of breeding sites, which mainly occurs at the end of the rainy season (September to December), when increasing the number of stagnant water (Paraense, 1972; Grisolia and Freitas, 1985; Juberg et al., 1987). Despite being basically harmful, established snail populations may flush out snails leading to the formation of new habitats (WHO, 1957).

Our models presented high predictive accuracy given that AUC values $>0.75$ should be considered excellent according to Phillips et al. (2006). Snail distribution and consequently also cases of schistosomiasis could be modelled from the environmental and climatic characteristics and therefore the maps of the distribution of Biomphalaria obtained can be used as predictors for the distribution of $S$. mansoni. Since schistosomiasis is a disease with distribution determined by the structural and contextual components of the environment, geoprocessing should be a powerful tool for unravelling the causal factors and analyzing the risk of occurrence of this disease in space and time (Guimarães et al., 2010).

\section{Conclusions}

This study showed areas of potential occurrence of Biomphalaria spp. snails. This facilitates the estimation of schistosomiasis in MRR by pointing out the variables that contribute to the expansion of this disease, allowing the application of effective measures to its prevention and control.

\section{References}

Alvares CA, Stape JL, Sentelhas PC, Gonçalves JLM, Sparovek G, 2013. Koppen's climate classification map for Brazil. Meteorol Z 22:71128.

Barbosa FS, Barbosa CS, 1994. The bioecology of snail vectors for schistosomiasis in Brazil. Cad Saúde Pública 10:200-9.

Barbosa CS, Domingues ALC, Abath F, Montenegro SML, Guida U,
Carneiro J, Tabosa B, Moraes CNL, Snipelli V, 2001. [Epidemia de esquistossomose aguda na praia de Porto de Galinhas, Pernambuco, Brasil]. [Article in Brazilian]. Cad Saúde Pública 17:725-8.

Barbosa CS, Araújo KC, Antunes L, Favre T, Pieri OS, 2004. Spatial distribution of schistosomiasis foci on Itamaracá Island, Pernambuco, Brazil. Mem I Oswaldo Cruz 99:79-83.

Barbosa CS, Favre TC, Wanderley TN, Callou AC, Pieri OS, 2006. Assessment of schistosomiasis, through school surveys, in the forest zone of Pernambuco, Brazil. Mem I Oswaldo Cruz 101:55-62.

Barbosa CS, Araújo KC, Sevilla MAA, Melo F, Gomes ECS, Souza-Santos $\mathrm{R}, 2010$. Current epidemiological status of schistosomiasis in the state of Pernambuco, Brazil. Mem I Oswaldo Cruz 105:549-54.

Barbosa CS, Barbosa VS, Nascimento WC, Pieri OS, Araújo KCGM, 2014. Study of the snail intermediate hosts for Schistosoma mansoni on Itamaracá Island in northeast Brazil: spatial displacement of Biomphalaria glabrata by Biomphalaria straminea. Geospat Health 8:345-51.

Bavia ME, Hale LF, Malone JB, Braud DH, Shane SM, 1999. Geographic information systems and the enviromental risk of Schistosomiasis in Bahia, Brazil. Am J Trop Med Hyg 60:566-72.

Brazilian Ministry of Health, 2009. [Guia de vigilância epidemiológica]. [Book in Brazilian]. Brazilian Ministry of Health, Brasília, Brazil.

Brazilian Ministry of Health, 2014. [Vigilância da Esquistossomose Mansoni: diretrizes técnicas]. [Book in Brazilian]. Brazilian Ministry of Health, Brasília, Brazil.

Câmara G, Casanova MA, Hemerly AS, Meghalaes GC, Medeiros CB, 1996. [Anatomia de sistemas de informação geográfica]. [Book in Brazilian]. Instituto de Computação, UNICAMP, Campinas, Brazil.

Camargo ECG, 1997. [Desenvolvimento, implementação e teste de procedimentos geoestatísticos (krigeagem) no Sistema de Processamento de Informações Georeferenciadas (SPRING)]. [Master's Degree in Brazilian]. INPE, São José dos Campos, Brazil.

Campos MR, Valencia LIO, Fortes BPMD, Braga RCC, Medronho RA, 2002. [Distribuição espacial da infecção por Ascaris lumbricoides]. [Article in Brazilian]. Rev Saúde Pública 36:69-74.

Cardim MFM, Rodas LAC, Dibo MR, Guirado MM, Oliveira AM, Chiaravalloti-Neto F, 2013. [Introdução e expansão da Leishmaniose visceral americana em humanos no estado de São Paulo, 1999-2011]. [Article in Brazilian]. Rev Saúde Pública 47:691-700.

Castro MC, Singer BH, 2007. [Meio ambiente e saúde: metodologia para análise espacial da ocorrência de malária em projetos de assentamento]. [Article in Brazilian]. Rev Bras Est Pop 24:247-62.

CPRH, 2003a. [Diagnóstico socioambiental do litoral norte de Pernambuco]. [Book in Brazilian]. Companhia Pernambucana do Meio Ambiente, Recife, Brazil.

CPRH, 2003b. [Diagnóstico socioambiental do litoral sul de Pernambuco]. [Book in Brazilian]. Companhia Pernambucana do Meio Ambiente, Recife, Brazil.

Cross ER, Bailey RC, 1984. Prediction of areas endemic for schistosomiasis through use of discriminant analysis of environmental data. Mil Med 149:28-30.

Elith J, Phillips SJ, Hastie T, Dudík M, Chee YE, Yates CJ, 2011. A statistical explanation of MaxEnt for ecologists. Diversity and Distributions 17:43-57.

Felgueiras CA, 1999. [Modelagem ambiental com tratamento de incertezas em sistemas de informação geográfica: o paradigma geoestatístico por indicação]. [PhD Thesis in Brazilian]. INPE, São José 
dos Campos, Brazil.

Fortes BPMD, Valencia LI0, Ribeiro SV, Medronho RA, 2004. [Modelagem geoestatística da infecção por Ascaris lumbricoides]. [Article in Brazilian]. Cad Saúde Pública 20:727-34.

Grisolia MLM, Freitas JR, 1985. [Características físicas e químicas do habitat da Biomphalaria tenagophila (Mollusca, Planorbidae)]. [Article in Brazilian]. Mem I Oswaldo Cruz 80:237-44.

Guimarães RJPS, Freitas CC, Dutra LV, Felgueiras CA, Moura ACM, Amaral RS, Drummond SC, Scholte RGC, Oliveira G, Carvalho 0, 2009. Spatial distribution of Biomphalaria snails at São Francisco River Basin, Minas Gerais, Brazil, using geostatistical procedures. Acta Trop 109:181-6.

Guimarães RJPS, Freitas CC, Dutra LV, Scholte RGC, Martins-Bedé FT, Fonseca FR, Amaral RS, Drummond SC, Felgueiras CA, Oliveira GC, Carvalho OS, 2010. A geoprocessing approach for studying and controlling schistosomiasis in the state of Minas Gerais, Brazil. Mem I Oswaldo Cruz 105:524-31.

Guimarães RJPS, Freitas CC, Dutra LV, Felgueiras CA, Drummond SC, Tibiriçá SHC, Oliveira G, Carvalho OS, 2012. Use of indicator Kriging to investigate schistosomiasis in Minas Gerais State, Brazil. J Trop Med 2012:1-10.

Isaaks EH, Srivastava RM, 1989. An introduction to applied geostatistics. Oxford University Press, New York, USA.

Juberg P, Schall VT, Barbosa JV, Gatti MJ, Soares MS, 1987. Behavior of Biomphalaria glabrata, the intermediate host snail of Schistosoma mansoni, at different depths in water in laboratory conditions. Mem I Oswaldo Cruz 82:179-208.

Lourenço RW, Landim PMB, 2005. [Mapeamento de áreas de risco à saúde pública por meio de métodos geoestatísticos]. [Article in Brazilian]. Cad Saúde Pública 21:150-60.

Lutz A, 1919. [0 Schistosoma mansoni e a Schistosomose segundo observações feitas no Brasil]. [Article in Brazilian]. Mem I Oswaldo Cruz 11:121-55.

Malek EA, 1958. Factors conditioning the habitat of bilharziasis inter- mediate hosts of the family phanorbidae. B World Health Organ 18:785-818.

Paraense WL, 1972. [Fauna planorbídica do Brasil]. In: Da Silva Lacaz C, Baruzzi RG, Siqueira WJ, eds. [Introdução à geografia médica do Brasil]. [Book in Brazilian]. Edgard Blucher, São Paulo, Brazil, pp. 213-39.

Phillips SJ, Dudik M, Schapire RE, 2004. A maximum entropy approach to species distribution modeling. ACM Press, New York, USA.

Phillips SJ, Anderson RP, Scharpire RE, 2006. Maximum entropy modeling of species geographic distributions. Ecol Model 190:231-59.

Pieri 0, Favre TC, 2008. [Manual prático para o controle e diagnóstico da esquistossomose]. [Book in Brazilian]. Ed. Universitária UFPE, Recife, Brazil.

Rey L, 2008. [Parasitologia]. [Book in Brazilian]. Guanabara Koogan, Rio de Janeiro, Brazil.

Samy AM, Campbell LP, Peterson AT, 2014. Leishmaniasis transmission: distribution and coarse-resolution ecology of two vectors and two parasites in Egypt. Rev Soc Bras Med Trop 47:57-62.

Scholte RGC, Carvalho OS, Malone JB, Utzinger J, Vounatsou P, 2012. Spatial distribution of Biomphalaria spp., the intermediate host snails of Schistosoma mansoni, in Brazil. Geospat Health 6:95-101.

Shad R, Mesgari MS, Abkar A, Shad A, 2009. Predicting air pollution using fuzzy genetic linear membership kriging in GIS. Comput Environ Urban 33:472-81.

Silva PB, Barbosa CS, Pieri 0, Travassos A, Florencio L, 2006. [Aspectos físico-químicos e biológicos relacionados à ocorrência de Biomphalaria glabrata em focos litorâneos da esquistossomose em Pernambuco]. [Article in Brazilian]. Qim Nova 29:901-6.

Souza MAA, Barbosa VS, Wanderlei TNG, Barbosa CS, 2008. [Criadouros de Biomphalaria, temporários e permanentes, em Jaboatão dos Guararapes, PE]. [Article in Brazilian]. Rev Soc Bras Med Trop 41:252-6.

WHO, 1957. Study group on the ecology of intermediate hosts of bilharziasis. World Health Organization, Geneva, Switzerland. 